\title{
地域医療を再定義する一「地域医療のコアを考える会」の 取り組み
}

Toward a Redefinition of Community Medicine-Trial of "Study Group to Discuss what are Cores of Community Medicine"

\author{
外山尚 吾 ${ }^{1)}$ 池 尻 達 紀 ${ }^{1)}$ 小林 充 ${ }^{2)}$ \\ Shogo Toyama ${ }^{1}$, Tatsuki Ikejiri ${ }^{1}$, Mitsuru Kobayashi ${ }^{2)}$
}

\begin{abstract}
要 旨
現在，「地域医療」の重要性が盛んに提唱されている。しかしながら，「地域医療」という用語は非常に多義的 に用いられており，その定義について広くコンセンサスが得られているとは言い難い，その背景を踏まえ，筆 者らは, 「地域医療」という用語の意味するところを整理して議論をするため, 学生と医療従事者らが対話的に 「地域医療のコア」を検討する勉強会を行っている.
\end{abstract}

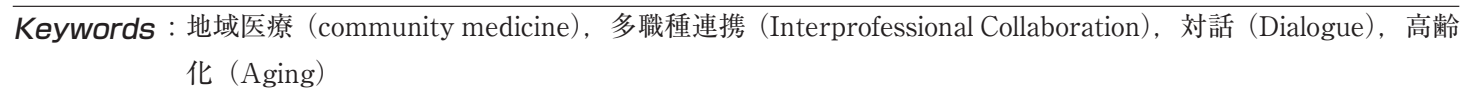

高齢化の加速や社会構造の変化に伴い, 平成 19 年改 定版コア・カリキュラムで「地域医療」の項目が新た に設けられるなど,「地域医療」の重要性が盛んに提唱 されている1 . しかし現状，「地域医療」という用語は 非常に多義的に用いられており ${ }^{2)}$, その定義についてコ ンセンサスが得られているとは言い難く,「『話者に とっての』地域医療論」が各所で繰り広げられている ように思える、そこで筆者らは「地域医療」の意味す るところを整理し議論することが必要ではないかと考 えた。

歴史を紐解くと, 敗戦後から高度成長期にかけての 日本の医療では病院を訪れる患者を治療するのが当た り前だったなか, 長野県の佐久総合病院で職員が地域 に出向き住民の生活を調查するという活動が行われ, これが地域に根ざした医療活動の走りである ${ }^{33}$. その後 1980 年の地域医療研究会にて, 佐久市立浅間総合病院 の吉沢国雄が「包括医療（広く保健予防, 健康増進, 疾病の早期発見, 診療, 後療法, 更生医療) を地域に 社会的に適応し実践すること」という地域医療の定義
を紹介し，これを Community Medicine に対応する概 念として論じだ).

昨今では「地域医療」は, 「僻地医療」総合診療医の 医療」等と混同して用いられる場面も多いが，以上の 歴史を踏まえると「地域に根ざした医療」という解釈 も可能であろう。しかしその「地域に根ざした医療」と いう定義もまた抽象的・変動的であるため, その意味 する具体的内容は時代背景・社会構造にあわせ繰り返 し検討し, 適宜再定義を行う必要があると考えられる.

このような問題意識のもと, 現代の「地域医療」に おいて重要かもしれないと考えたテーマを任意に設定 し, それらを掘り下げる過程で「地域医療のコア領域 は何か」を独自の視点から検討することを目指した勉 強会「地域医療のコアを考元る会（以下コア研と略 す)」を 2016 年 6 月 29 日に発足させた. 各回の人数は 定まっていないが, 医師約 2 名, 学生約 4 名, 事務職 員約 2 名に加え, 各回のテーマに応じて看護師, Medical Social Worker (MSW), Psychiatric Social Worker (PSW), ケアマネージャーといったゲストを迎え，

1) 京都大学医学部医学科

2) 民医連第二中央病院

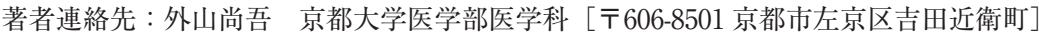

email: shogo106.outmt.bunri.2@gmail.com

(受付日：2018 年 2 月 6 日, 採用日：2018 年 6 月 14 日)

(C)2018 日本プライマリ・ケア連合学会 
数ヶ月に 1 回のペースで京都民医連第二中央病院にて 実施してきた。これまでの参加者は, のべ人数で医師 4 名（神経内科医 1 名, 総合診療医 2 名, 精神科医 1 名), 医学生 18 名, 看護学生 1 名, 看護師 5 名, MSW 2 名, PSW1 名, ケアマネージャー 1 名, 事務職員等 4 名である. 2017 年 12 月 1 日現在まで計七回が行われ ている. 扱ったテーマはいずれも「地域医療における」 と限定しており,「コミュニケーション」「終末期のケ ア・死生観」「貧困・経済的問題」「メンタルヘルス」「信 仰」「在宅医療」医療者のワークライフバランス」であ る.

コア研では上述の多様な職種の方々からの事例紹介 を起点とし議論を展開する，その議論で繰り返し出て きたポイントのうち, 議論全体の様々な具体的事項に 共通して応用できると考えられる抽象度の高いものを 「仮の」「コア」として設定している。議論は各回の始め に医療者から提供される話題に大きく依存するため, ある程度場当たり的になり, 回数を重ねなければ妥当 性を持ち得ない．故にここまで設定したコアは仮のも のであり, 今後さらに議論や仮の「コア」や議論の内 容を抽象化することを繰り返しつつ, コア研以外の新 たな方法を併用するトライアンギュレーションを試み 「コア」をより妥当なものにしていきたいと考えてい る.

これまで設定した「コア」は「地域医療」という排 他的で輪郭のはっきりしたイメージを始めに持ってか ら，そのイメージにより合致するトピックを持ってく るというょり, 在宅医療の現場や近隣の住民が患者と して訪れる症例などを中心とした筆者らがより地域に 根ざしていると受け取った事例を参考に, 地域医療と は何かを今後議論して行く上での題材となりそうな卜 ピックを学生の視点から選んでいる. 従って, 従来か ら地域医療にとって重要と考えられていることもそう でないことも混在するが，それらが今後の議論の吒き 台になれば筆者らの意図するところである.

これまでのところコア研を通じて筆者らが考えた 「コア」をいくつか紹介したい.

第二回のコア研での事例紹介は, 医師がとある認知 症患者の担当になった際, 万が一の場合の救命措置の 方向性について, 家族に意思確認したところ,「他施設 に頼れとは責任を放裹するのか」と怒りを買ってし まったという体験であった，その分析として医師の側 は，ご家族と先生が初対面でラポールが形成されてい なかったことを挙げたが, 医学生からは,「医師が問い かけに対する答えをすでに持っていて，その答えを強
要されているかのような気持ちになっていたのではな いか」というような学生ならではの意見が挙げられた。

高齢化が加速する現状のなかで, 「認知症患者への対 応ニーズ」は高まるばかりである。ささらに地域医療の 現場で認知症症患などの慢性疾患患者が多く, 患者の 社会的背景のばらつきも大きいのではないかという仮 定のもと,「医師患者コミュニケーションにおける個別 性」というコア要素を設定した.

また, 第七回目のコア研では, 「誤嚥性肺炎の危険性 があるが好きなものを食べたい」という患者の事例に ついて議論した。 学生から, 患者の主観的満足にいか に向き合っているのかについての疑問が呈されたとこ 万, 「臨床倫理 4 分割」5) 「医学的な妥当性」「患者の意 向」「QOL」「周囲の状況」をもとに考えているという答 えが現場の医師からあった. 加えて,「在宅においては 個別性を重視している」という医師の指摘もあり，「価 值観を重視した個別性」が地域医療のコアであること が再確認された.

関連して, 医師によって「在宅医療での最大の問題 は, 良いケアが受けられるのかという『不安』と, 介 護における『負担』である」という指摘がなされた。 それを受け学生から, 市民の立場として, 病を抱えた まま地域で暮らすことについての不安について述べら れ, 家族の不安をいかに取り除くのかということにつ いて議論がなされた。

在宅看護を始める家族は，「自分だけが頼りである」 という責任感や「自分の時間をとれなくなる」負担感 から, 強いストレスを感じている ${ }^{6}$. よって地域医療に おける医療者は, そのストレスを取り除く助けもする ことが求められると考元られる.これを踏まえ,「在宅 看護を行う家族の負担軽減」もコアな要素であると設 定した.

七回の勉強会により，筆者らが現在までで考えたコ ア領域は，図１の通りである。

以上は議論のごく一部の抜粋である. 今後とも, 時 代によって変遷する地域医療を再定義する出発点の一 つを提示するため，筆者らはコア研を継続していきた いと考えている. 活動は試行錯誤の段階であり, さら に活動の性質上, 多くの方のご指摘やご参加をお願い したい.

\section{利益相反}

本報告に関連して, 筆者らに開示すべき COI はあり ません。 


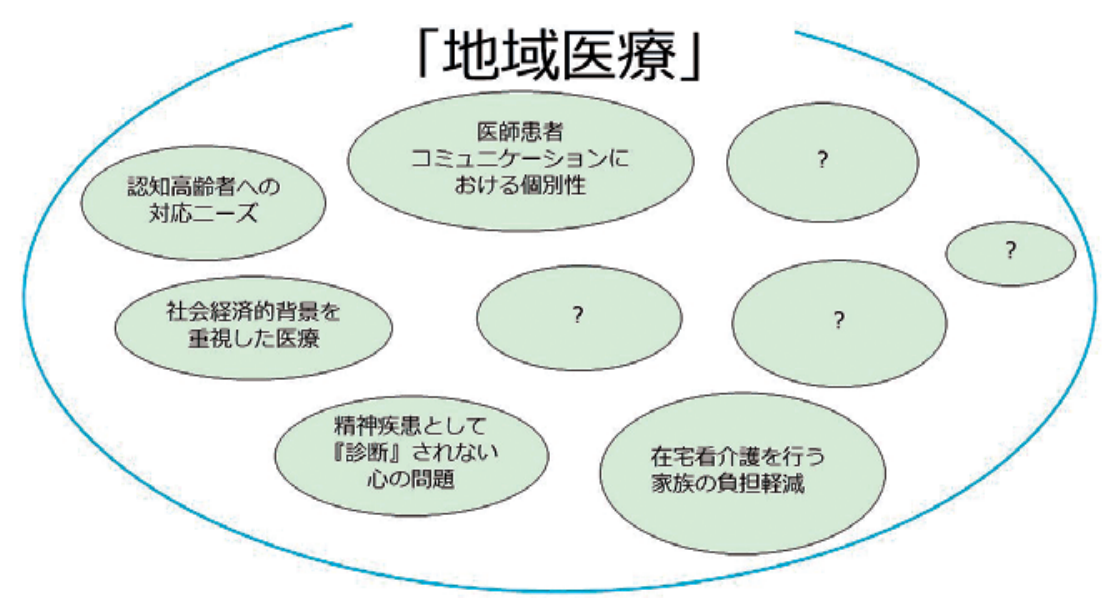

図 1

\section{文 献}

1）吉村明修.わが国の医学教育改革の流れとモデル・コ ア・カリキュラムの変遷. 日本医科大学医学会雑誌. $2012 ; 8$ (1) : 18-21.

2）上原里程, 森田喜紀, 神田健史, 他. 「地域医療」という 用語の多様性. 日本医事新報. $2012 ； 4619 ： 86-90$.

3）杉山章子. 農村医学の形成と発展一佐久病院における地 域医療活動の実践から。日本医史学雑誌. $2000 ； 46(4)$ ： 509 .
4）今井澄. 豊かな明日への暮らしと医療. 第 1 版. 東京：鳥 影社；1992.167.

5) Albert R. Jonsen, 他. 臨床倫理学一臨床医学における倫理 的決定のための実践的なアプローチ. 第 5 版. 赤羽朗, 蔵 田伸雄, 児玉聡監訳. 東京都 : 新興医学出版社 ; 2006.213.

6）上村さと美，秋山純和. Zarit 介護負担尺度日本語版（JZBI）を用いた家族介護者の介護負担感評価. $2007 ; 2$ (1) : 61-65. 